\title{
Short communication: Metritis affects milk production and cull rate of Holstein multiparous and primiparous dairy cows differently
}

\author{
J. M. Wittrock, K. L. Proudfoot, D. M. Weary, and M. A. G. von Keyserlingk ${ }^{1}$ \\ Animal Welfare Program, Faculty of Land and Food Systems, University of British Columbia, 2357 Main Mall, Vancouver, \\ British Columbia, V6T 1Z4, Canada
}

\begin{abstract}
Metritis, a common transition disease in dairy cows, reduces milk production during the duration of the disease. To our knowledge, no work has investigated the short-term effects of metritis on feed intake and the long-term consequences on milk yield and risk of culling. The objectives were to determine the effect of metritis on 305-d lactation curves, dry matter intake (DMI), reproduction, and the probability of being culled. Identifying differences in response to metritis between primiparous and multiparous cows was of interest. Milk records were collected twice daily from Holstein cows diagnosed with puerperal metritis (11 primiparous and 16 multiparous) or classified as healthy (14 primiparous and 43 multiparous) during the first 3 wk after calving. Metritic cows were treated at the discretion of the herd veterinarian. Lactation curves of healthy and metritic cows were compared using a mixed model with a Wilmink function. Differences in DMI, days open, and the number of services per conception were assessed using mixed models. The probabilities that cows with and without metritis were not bred, were bred but never confirmed pregnant, or were culled were compared using Fisher's exact tests. Primiparous and multiparous animals were assessed separately. Multiparous cows with metritis produced less milk $(35.1 \pm 1.5$ vs. $39.2 \pm$ $1.0 \mathrm{~kg} / \mathrm{d})$, ate less during the $3 \mathrm{wk}$ after calving (12.2 \pm 1.2 vs. $14.0 \pm 0.8 \mathrm{~kg} / \mathrm{d}$ ), and were more likely to be culled (50.0\%) than healthy cows $(20.9 \%)$. The decision to cull was likely influenced by the lower milk yield in early lactation as a result of metritis; the decision to cull was made early, as 7 of the 8 culled metritic cows were not bred. No differences were found in any measurement between primiparous cows with and without metritis. These results indicate that metritis in early lactation has long-term effects on multiparous cows but not primiparous cows.
\end{abstract}

Key words: transition, health, parity, mortality

Received August 8, 2010.

Accepted January 17, 2011.

${ }^{1}$ Corresponding author: nina@interchange.ubc.ca

\section{Short Communication}

Lactating dairy cows are susceptible to numerous infectious and metabolic diseases during the early postpartum period. These diseases are associated with the abrupt shift in nutritional demands and physiological processes occurring during this time (Goff and Horst, 1997). Puerperal metritis, or early metritis, is a postpartum disease known to reduce milk yield (Rajala and Gröhn, 1998) and feed intake (Huzzey et al., 2007), and to negatively affect reproductive performance (Opsomer et al., 2000; Melendez et al., 2004).

Puerperal metritis is an acute bacterial uterine infection that normally manifests within $21 \mathrm{~d}$ after calving (Sheldon et al., 2006). The infection is characterized by fetid red-brown watery uterine discharge, often accompanied by symptoms common to systemic infections including pyrexia, inappetance, depression, and decreased milk production (Sheldon et al., 2006, 2008). Endometritis typically occurs 21 or more days after calving and is classified as the presence of purulent uterine discharge with the absence of systemic infection indicators (Sheldon et al., 2006). This paper focuses on puerperal metritis, referred to simply as "metritis".

Some discrepancy exists in the literature about the effect of metritis on milk yield. Some studies have reported decreased yield (Deluyker et al., 1991; Simerl et al., 1992; Rajala and Gröhn, 1998), but others show no or equivocal effects of the disease on yield (Markusfeld and Ezra, 1993; Goshen and Shpigel, 2006). This discrepancy may be partially explained by differences in parity. Østergaard and Gröhn (1999) found that multiparous cows, but not primiparous cows, with metritis produced less milk than healthy cows up to 6 wk after diagnosis. This parity effect has remained unexplained, but may be due to differences in feed intake. Huzzey et al. (2007) found that ill cows consumed less feed than healthy cows; yet, this has not been tested in primiparous and multiparous cows separately.

Metritis and other infections of the reproductive tract can harm reproductive performance (Sheldon et al., 2006). Cows with metritis have increased days between first service after calving and conception, increasing the efforts and resources required to induce pregnancy (Erb 
et al., 1981; Fourichon et al., 2000). Reproductive status is the most important influence on culling decisions (Gröhn et al., 2003), so it seems likely that uterine infections increase the risk of culling. The objectives were to determine the effects of metritis on 305-d milk production, DMI, and culling on primiparous and multiparous cows separately.

Milk production, DMI, culling, and reproduction records were taken from Holstein dairy cows (66 primiparous and 146 multiparous) housed at The University of British Columbia's Dairy Education and Research Centre (Agassiz, British Columbia, Canada). Animals were cared for according to the guidelines of the Canadian Council on Animal Care (1993). Data were collected from 2 experiments; housing conditions were as described by Huzzey et al. (2007) and Proudfoot et al. (2009). In the latter study, cows were in 1 of 2 treatments (competitive versus noncompetitive feeding environments), but treatment had no effect on metritis, production, or culling risk so this treatment is not described further.

Metritis was diagnosed using vaginal discharge (VD) scoring conducted every $3 \mathrm{~d}$ after calving until 21 DIM. The appearance and smell of the VD was assigned to 1 of 4 categories based on the scoring system used by Urton et al. (2005): no mucus or clear mucus $=0$; cloudy mucus with flecks of pus $=1$; mucopurulent $(\leq 50 \%$ pus present) and foul smelling $=2$; purulent $(>50 \%$ pus present) and foul smelling $=3$; or putrid (red or brown color, watery, foul smelling) $=4$. Rectal temperature was taken daily at approximately $0900 \mathrm{~h}$ from d 1 to $\mathrm{d} 21$ postcalving using a digital thermometer (GLA M525/550, GLA Agricultural Electronics, San Luis Obispo, CA).

Cows were classified as having puerperal metritis if they had at least $1 \mathrm{VD}$ score of 4 and 1 recorded fever $\left(\geq 39.6^{\circ} \mathrm{C}\right)$ within $\pm 1 \mathrm{~d}$ of the VD score of 4 . These cows were treated at the discretion of the herd veterinarian. Healthy cows had no fever $\left(<39.6^{\circ} \mathrm{C}\right)$ after calving, a maximum VD score of 1 , and no other health complications. Cows that exhibited clinical signs of other diseases during the $21 \mathrm{~d}$ precalving and first $21 \mathrm{DIM}$ were not included in the study, ensuring that the effect of metritis on milk yields were not confounded by other transition diseases and could be attributed to metritis alone. Cows diagnosed with subclinical metritis $(\mathrm{n}=$ $67)$, clinical mastitis $(\mathrm{n}=23)$, clinical ketosis or milk fever $(\mathrm{n}=11)$, or a combination of disorders (i.e., including fever, lameness, displaced abomasum, and dystocia; $\mathrm{n}=27$ ) were not included. Cows with both severe metritis and retained placenta $(\mathrm{n}=11)$ were included in the study. Thus, of the 212 cows pooled from the 2 experiments, 84 cows were included in the study: 27 with metritis (11 primiparous and 16 multiparous) and 57 healthy cows (14 primiparous and 43 multiparous).

Milk weights were collected automatically twice daily by DairyComp 305 (Valley Agricultural Software, Tulare, CA). The resulting milk yields were summed for each day. Daily milk yields were then averaged by week of lactation to a total of $44 \mathrm{wk}$ (305 d). The number of cows in each group that were bred, their days open, and the number of services before confirmed or unconfirmed pregnancy were collected from DairyComp 305.

Feed intake data was collected daily for the first $3 \mathrm{wk}$ of lactation using electronic feed bins (Insentec, Marknesse, Holland). The feed bins recorded individual feed intakes of group-housed cows; weights of feed consumed during each visit to the bins were summed per day and cow to generate daily feed intakes. Samples of pre- and postcalving TMR were taken 3 times per week and pooled before analysis. Samples were dried at $60^{\circ} \mathrm{C}$ for $2 \mathrm{~d}$ to determine DM; this information was then used to correct daily feed intakes for DMI. Feeding occurred twice daily at approximately 0800 and $1600 \mathrm{~h}$.

Cow was considered the observational unit $(\mathrm{n}=84)$. Primiparous and multiparous animals were analyzed separately in all statistical tests. A mixed model in SAS (version 9.1, 2003, SAS Institute Inc., Cary, NC) was used to analyze the differences in milk production between healthy and metritic animals during a standardized 305-d period. Weekly data were modeled using a Wilmink function (Wilmink, 1987) as suggested by Olori and Galesloot (1999). The type I analysis included variables in the following order: week $\mathrm{e}^{-0.05 \text { (week) }}$, health (healthy or metritis), week by health and $\mathrm{e}^{-0.05 \text { (week) }}$ by health interactions and used a Kenward-Roger degrees of freedom method. Intercept was considered a random effect in the model.

Differences in the number of cows bred and the number of cows with unconfirmed pregnancies after multiple services in each group were tested using Fisher's exact tests. Differences in the number of days open and services before confirmed pregnancy were tested in a mixed model that included health as a fixed effect and experiment as a random effect.

Daily DMI records were averaged over the first 3 wk of calving for each cow. Differences in feed intake between healthy and metritic cows were tested in a mixed model that included health as a fixed effect and experiment as a random effect.

The effect of metritis on the number of cows culled was tested using a Fisher's exact test. Cows that were culled may have had lower production in the weeks before culling for several reasons other than metritis. To determine if cows that were subsequently culled had lower production independent of metritis, 8 cows with 


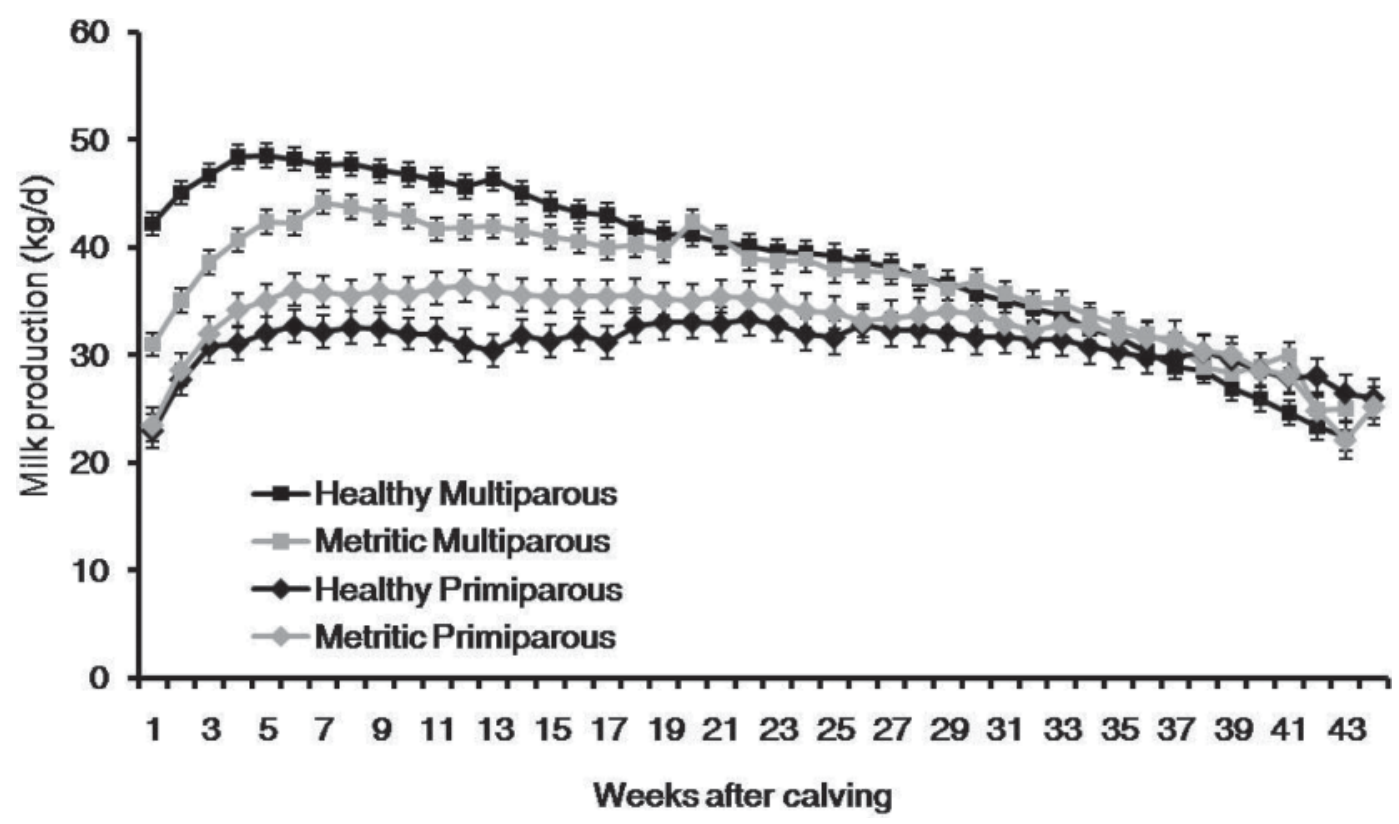

Figure 1. Milk yields (kg/d averaged over weekly periods) for primiparous and multiparous cows diagnosed with metritis $(\mathrm{n}=11$ and 16 , respectively) or that remained healthy ( $\mathrm{n}=14$ and 43 , respectively) during 3 wk postcalving. Data are from cows that survived as well as those that were culled.

and without metritis that were not culled were balanced for previous lactation with 8 cows with and without metritis that were culled. The earliest cull was $13 \mathrm{wk}$ after calving, so differences in milk production were tested during the first $12 \mathrm{wk}$ of lactation. Means were compared using a mixed model that included health (healthy or metritis), cull status (cull or no cull), a health by cull status interaction, and experiment as a random effect. Pairwise comparisons between metritic and healthy cows within cull status were with a Tukey post-hoc test.

Multiparous cows with metritis in early lactation produced less than those that remained healthy (Figure $1 ; P=0.03)$. This difference was greatest during the first $20 \mathrm{wk}$ of lactation. Metritis caused a reduction in DMI of multiparous cows during the 3 wk after calving (Figure 2; $P<0.01$ ). Metritic multiparous cows were more likely to be culled than healthy cows (Table $1 ; P$ $=0.05)$. Of the 8 metritic cows culled, 7 were not bred. Healthy and metritic multiparous cows did not differ in number of services $(2.1 \pm 0.3$ vs. $2.1 \pm 0.5, P=0.98)$, days open (107 \pm 10 vs. $112 \pm 18 ; P=0.82$ ), or probability of cows having unconfirmed pregnancies after multiple services (14.3 vs. $11.1 \% ; P=0.76)$.

In the 12 wk after calving, cows that were culled produced less than cows that were not culled (42.6 \pm 1.6 vs. $50.6 \pm 2.0 \mathrm{~kg} / \mathrm{d} ; P=0.003$ ). When pairwise comparisons were made within cull status, a tendency was observed for metritic cows to produce less than healthy cows among cows that were later culled (38.9 \pm
2.0 vs. $46.3 \pm 2.1 \mathrm{~kg} / \mathrm{d} ; P=0.09)$, but not for nonculled animals $(49.6 \pm 2.6$ vs. $51.6 \pm 2.2 \mathrm{~kg} / \mathrm{d} ; P=0.48)$.

Healthy and metritic primiparous cows did not differ in lactation curves (Figure 1; $P=0.30$ ), feed intake during the $3 \mathrm{wk}$ after calving $(P=0.86)$, or their probability of being culled $(P=0.49)$. Healthy and metritic primiparous cows did not differ in number of services $(2.4 \pm 0.4$ vs. $1.6 \pm 0.4 ; P=0.19)$, days open $(93 \pm 16$ vs. $106 \pm 17 ; P=0.59)$, or probability of cows not bred

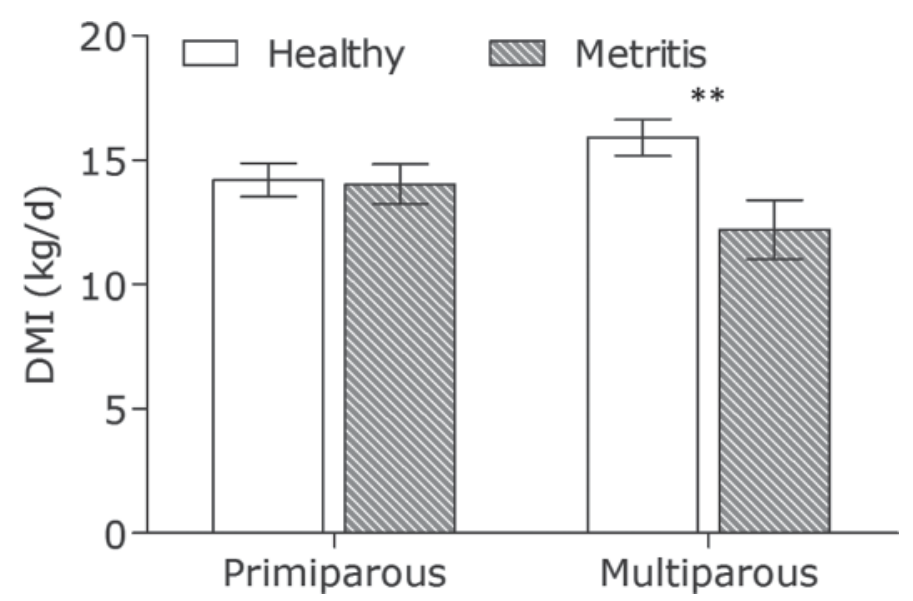

Figure 2. Dry matter intake $(\mathrm{kg} / \mathrm{d})$ during the 3 wk after calving for primiparous and multiparous cows that were diagnosed with metritis $(\mathrm{n}=11$ and 16 , respectively) and those that remained healthy $(\mathrm{n}=$ 14 and 43 , respectively) during 3 wk postcalving. ${ }^{* *} P<0.01$. 
Table 1. A comparison of cull rates over the lactation for multiparous and primiparous cows diagnosed with metritis compared with cows that remained healthy

\begin{tabular}{|c|c|c|c|c|c|c|}
\hline \multirow[b]{2}{*}{ Item } & \multicolumn{2}{|c|}{ Multiparous cows } & \multirow[b]{2}{*}{$P$-value ${ }^{1}$} & \multicolumn{2}{|c|}{ Primiparous cows } & \multirow[b]{2}{*}{$P$-value ${ }^{1}$} \\
\hline & Healthy & Metritis & & Healthy & Metritis & \\
\hline Total (n) & 43 & 16 & & 14 & 11 & \\
\hline Culled (n) & 9 & 8 & & 2 & 0 & \\
\hline Culled (\%) & 20.9 & 50.0 & 0.05 & 14.3 & 0 & 0.49 \\
\hline Not bred (n) & 5 & 7 & & 1 & 0 & \\
\hline Not bred $(\%)$ & 11.9 & 38.9 & 0.02 & 7 & 0 & 0.99 \\
\hline
\end{tabular}

${ }^{1}$ Fisher's exact test was used to calculate $P$-values.

or with unconfirmed pregnancies after multiple services ( 28.6 vs. $27.3 \% ; P=0.70)$.

Our results are the first to show the effect of puerperal metritis on milk production over $305 \mathrm{~d}$, feed intake, and cull status in multiparous and primiparous cows separately. Multiparous cows with metritis ate less during the 3 wk after calving, produced less milk up to 20 wk into lactation, and were more likely to be culled by $305 \mathrm{~d}$. The reduction in long-term milk production may be partially driven by a decline in feed intake (Bell and Roberts, 2007), supporting Huzzey et al. (2007). It remains unclear if DMI was lower in metritic cows beyond 3 wk in milk; however, intake and production during the first few weeks of lactation can predict longterm production (Lean et al., 1989).

Multiparous cows with metritis were more likely culled, and culling decisions were made before any indications of reproductive problems (indeed, most of the culled cows were never bred). The decision to cull was likely driven by a combination of ill health and low production in the first weeks of lactation.

Primiparous cows with metritis did not differ from healthy cows in terms of DMI, milk production, or cull rate. The sustained DMI in sick primiparous cows may partially explain the lack of difference in milk production. This difference may help explain why primiparous cows with metritis were not more likely culled compared with healthy cows. Primiparous cows have a faster immune response to infection (Lessard et al., 2004) and may recover from metritis faster than multiparous cows. An acute reduction in DMI is still expected at the onset of disease (Waldron et al. 2006); the lack of response in primiparous cows remains unclear and deserves further exploration.

In summary, puerperal metritis reduces acute feed intake, long-term milk yield, and increases the chance of culling in multiparous cows but not primiparous cows.

\section{ACKNOWLEDGMENTS}

We thank Julie Huzzey and the faculty, staff, and students at University of British Columbia's Dairy Educa- tion and Research Centre and the University's Animal Welfare Program. Julie Wittrock was supported in part by a Natural Sciences and Engineering Research Council (NSERC) of Canada (Ottawa, ON, Canada) Undergraduate Scholarship. The Animal Welfare Program is funded by Canada's NSERC Industrial Research Chair Program with industry contributions from the Dairy Farmers of Canada (Ottawa, ON, Canada), Westgen Endowment Fund (Milner, BC, Canada), Pfizer Animal Health (Kirkland, QC, Canada), BC Cattle Industry Development Fund (Kamloops, BC, Canada), the BC Milk Producers (Burnaby, BC, Canada), BC Dairy Foundation (Burnaby, BC, Canada), BC Dairy Education and Research Association (Abbotsford, BC, Canada), and Alberta Milk (Edmonton, AB, Canada).

\section{REFERENCES}

Bell, M. J., and D. J. Roberts. 2007. The impact of uterine infection on a dairy cow's performance. Theriogenology 68:1074-1079.

Canadian Council on Animal Care. 1993. Guide to the Care and Use of Experimental Animals. Vol. 1. E. D. Olfert, B. M. Cross, and A. A. McWilliam, ed. Can. Counc. Anim. Care, Ottawa, Ontario, Canada.

Deluyker, H. A., J. M. Gay, L. D. Weaver, and A. S. Azari. 1991. Change of milk yield with clinical diseases for a high producing dairy herd. J. Dairy Sci. 74:436-445.

Erb, H. N., S. W. Martin, N. Ison, and S. Swaminathan. 1981. Interrelationships between production and reproductive diseases in Holstein cows: Path analysis. J. Dairy Sci. 64:282-289.

Fourichon, C., H. Seegers, and X. Malher. 2000. Effect of disease on reproduction in the dairy cow: A meta-analysis. Theriogenology 53:1729-1759.

Goff, J. P., and R. L. Horst. 1997. Physiological changes at parturition and their relationships to metabolic disorders. J. Dairy Sci. 80:1260-1268.

Goshen, T., and N. Y. Shpigel. 2006. Evaluation of intrauterine antibiotic treatment of clinical metritis and retained fetal membranes in dairy cows. Theriogenology 66:2210-2218.

Gröhn, Y. T., P. J. Rajala-Schultz, H. G. Allore, M. A. DeLorenzo, J. A. Hertl, and D. Galligan. 2003. Optimizing replacement of dairy cows: Modeling the effects of diseases. Prev. Vet. Med. 61:27-43.

Huzzey, J. M., D. M. Veira, D. M. Weary, and M. A. G. von Keyserlingk. 2007. Prepartum behavior and dry matter intake identify dairy cows at risk for metritis. J. Dairy Sci. 90:3220-3233.

Lean, I. J., J. C. Galland, and J. L. Scott. 1989. Relationships between fertility, peak milk yields and lactational persistency in dairy cows. Theriogenology 31:1093-1103.

Lessard, M., N. Gagnon, D. L. Godson, and H. V. Petit. 2004. Influence of parturition and diets enriched in n-3 or n- 6 polyunsatu- 
rated fatty acids on immune response of dairy cows during the transition period. J. Dairy Sci. 87:2197-2210.

Markusfeld, O., and E. Ezra. 1993. Body measurements, metritis, and postpartum performance of first lactation cows. J. Dairy Sci. 76:3771-3777.

Melendez, P., J. McHale, J. Bartolome, L. F. Archbald, and G. A. Donovan. 2004. Uterine involution and fertility of Holstein cows subsequent to early post partum $\mathrm{PGF}_{2 \alpha}$ treatment for acute puerperal metritis. J. Dairy Sci. 87:3238-3246.

Olori, V. E., and P. J. B. Galesloot. 1999. Projection of partial lactation records and calculation of 305-day yields in the Republic of Ireland. Interbull Bull. 22:149-154.

Opsomer, G., Y. T. Gröhn, J. Hertl, M. Coryn, H. Deluyker, and A. de Kruif. 2000. Risk factors for post partum ovarian dysfunction in high producing dairy cows in Belgium: A field study. Theriogenology 53:841-857.

Østergaard, S., and Y. T. Gröhn. 1999. Effect of diseases on test day milk yield and body weight of dairy cows from Danish research herds. J. Dairy Sci. 82:1188-1201.

Proudfoot, K. L., D. M. Veira, D. M. Weary, and M. A. G. von Keyserlingk. 2009. Competition at the feed bunk changes the feeding, standing, and social behaviour of transition dairy cows. J. Dairy Sci. $92: 3116-3123$
Rajala, P. J., and Y. T. Gröhn. 1998. Effects of dystocia, retained placenta, and metritis on milk yield in dairy cows. J. Dairy Sci. 81:3172-3181.

Sheldon, I. M., G. S. Lewis, S. LeBlanc, and R. O. Gilbert. 2006. Defining postpartum uterine disease in cattle. Theriogenology 65:1516-1530.

Sheldon, I. M., E. J. Williams, A. N. A. Miller, D. M. Nash, and S. Herath. 2008. Uterine diseases in cattle after parturition. Vet. J. 176:115-121.

Simerl, N. A., C. J. Wilcox, and W. W. Thatcher. 1992. Postpartum performance of dairy heifers freshening at young ages. J. Dairy Sci. 75:590-595.

Urton, G., M. A. G. von Keyserlingk, and D. M. Weary. 2005. Feeding behavior identifies dairy cows at risk for metritis. J. Dairy Sci. 88:2843-2849.

Waldron, M. R., A. E. Kulick, A. W. Bell, and T. R. Overton. 2006. Acute experimental mastitis is not causal toward the development of energy-related metabolic disorders in early postpartum dairy cows. J. Dairy Sci. 89:596-610.

Wilmink, J. B. M. 1987. Adjustment of test-day milk, fat and protein yields for age, season and stage of lactation. Livest. Prod. Sci. $16: 335-348$. 